Abstract
This essay takes up Sally Mapstone's contention that Scottish advice to princes was directed
as much to magnates and their supporters as it ever was to the king, and applies it to Gavin
Douglas's Eneados. It considers the manner in which Douglas's translation represents
nobility, national identity, and political violence, with reference to Douglas's own magnatial
identity and that of the poem's patron, William Sinclair. It considers both the prologues and
the translated texts, examining further the relationship between them. In so doing, it places
the Eneados in the context of Virgilian criticism as well as Older Scots poetic traditions, and
demonstrates parallels in language choices regarding war, government, and rule.
Geywords




\title{
$<\mathrm{CN}>9$
}

\section{THE NOBLE IDENTITY OF GAVIN DOUGLAS}

\author{
Nicola Royan
}

On the title page of William Copland's 1553 print of the Eneados are these words:

The xiii bukes of Eneados of the famose Poete Virgill/ Translatet out of Latyne/ verses into Scottish me-/tir, bi the Reuerend Fa-ther in God, May-ster Gawin Douglas/ Bishop of Dunkel \&/ unkill to the Erle/ of Angus. Euery/ buke hauing hys/perticular/ Prologue. ${ }^{1}$

As might be expected, Douglas is identified by his qualification-Master of Arts, and by his job title-Bishop of Dunkeld. However, his nephew is also part of the sales pitch. By 1553, Angus was back in Scotland, recovering the possessions lost in his conflict with James V: it is not obvious how his name would have contributed much to the book's English (and possibly Scottish) sales. ${ }^{2}$ Nevertheless, Copland thought it worthwhile to associate this translation — and his printing — with aristocratic power. Why that should be in the 1550 s is

${ }^{1}$ Gavin Douglas, The xiii. bukes of Eneados (London,1553), title page. The edition of the Eneados used is Virgil's Aeneid translated into Scottish verse by Gavin Douglas, Bishop of Dunkeld, edited by D.F.C. Coldwell, 4 vols, STS (Edinburgh and London, 1957-60). All references are in the form of line numbers embedded in the text. The work for this essay was supported by a Fellowship from the Leverhulme Trust. I would also like to thank Professor Priscilla Bawcutt for her constructive reading of this essay.

${ }^{2}$ Marcus Merriman, 'Douglas, Archibald, Sixth Earl of Angus (c.1489-1557)', ODNB http://www.oxforddnb.com/view/article/7866 [accessed 21 July 2016]. 
important; in the 1510s, when the poem was completed and first circulated, there was less need to advertise the association, but the implications are no less significant. At that point, the identity of the writer, the nature of the intended audience, and what inflection the experience and knowledge of aristocratic power in both poet and readers might give to the Eneados all matter.

Douglas's family background is well known: ${ }^{3}$ it was crucial to his church career, and to his role in Scottish politics after 1513. This essay considers the importance of his ancestry to his poetry, particularly the Eneados, both in its matter and in its audience. Such an approach is intended neither to be narrowly biographical nor to suggest a worked-out Douglas family allegory: even if they were probable, such readings would be opposed to the more expansive view of potential audiences that Douglas presents in his prologues and epilogues. ${ }^{4}$ Nor, no matter how tempting, should the Eneados be read as direct comment on James IV's preparations to invade England in support of the French in spring $1513 .{ }^{5}$ Rather, the essay is concerned firstly to locate the Eneados in the milieu to which Douglas alludes in his dedication of the poem; and secondly to consider the ways in which the Eneados might serve as a piece of advice material. Given that on the one hand, Douglas dedicates his first poem, The Palice of Honour, to the King and his second, greater work to Henry Sinclair, and on the

${ }^{3}$ Gavin Douglas was the third son of the fifth Earl of Angus. He was educated at the University of St Andrews, completing his Master's degree in 1494, and entered the church, becoming provost of St Giles in Edinburgh by 1503, and finally Bishop of Dunkeld in 1516 (after the completion of the Eneados). See Priscilla Bawcutt, Gavin Douglas: A Critical Study (Edinburgh, 1976), pp. 1-22.

${ }^{4}$ In the prologue to Book I, Douglas imagines an audience of 'Beaw schirris' (I.Prol. 105) headed by Henry, Lord Sinclair (I.Prol.79-104); in 'Ane Exclamatioun' at the text's conclusion, he hopes his work will reach 'euery gentill Scot' ('Exclamatioun', 43).

\footnotetext{
${ }^{5}$ Norman Macdougall, James IV (East Linton, 1997), pp. 248-64.
} 
other, that the Aeneid itself is a political poem, it is entirely legitimate to consider the Eneados as a text with advice for the Scottish nobility by a Scottish nobleman. ${ }^{6}$

The Aeneid, written under Augustus, celebrating Rome's achievements and lamenting the civil wars that led to the Empire, had always carried political weight. By the sixteenth century, Aeneas, in some quarters, was understood as a model for Augustus. ${ }^{7}$ That view Douglas could certainly have found in Badius Ascensius' commentary, but in other places as well. ${ }^{8}$ If Aeneas was a model for Augustus, then he might also serve as a model for contemporary kingship, as had Alexander: translating the Aeneid might be seen simplistically as the humanist update on the fifteenth-century Scottish Alexander romances. ${ }^{9}$ Douglas himself draws attention to this tradition in the prologue to Book 1, where he says that 'euery vertu belangand a nobill man/ This ornate poet bettir than ony can/ Payntand discryvis in person of Eneas' (I.Prol.325-7).

Furthermore, Virgil's narrative is also concerned with the divinely ordained foundation of Rome. To some degree modelled on the Aeneid, many European kingdoms had similar

\footnotetext{
${ }^{6}$ For references to The Palice of Honoure, see The Shorter Poems of Gavin Douglas, edited by Priscilla Bawcutt, rev. ed. STS (Edinburgh, 2003): the dedication to James is at lines 2143-69.

${ }^{7}$ See Craig Kallendorf, The Other Virgil: 'Pessimistic' Readings of the Aeneid in Early Modern Culture (Oxford, 2007), p. 11.

${ }^{8}$ See David Scott Wilson-Okamura, Virgil in the Renaissance (Oxford, 2010), pp. 191-247 and Paul White, Jodocus Badius Ascensius: Commentary, Commerce and Print in the Renaissance (Oxford, 2013).
}

${ }^{9}$ See Joanna Martin, Kingship and Love in Scottish Poetry, 1424-1540 (Basingstoke, 2008), pp. 6178 and Sally Mapstone, 'Older Scots Literature and the Court', in The Edinburgh History of Scottish Literature, vol. 1: 'From Columba to the Union (until 1707)', edited by Thomas Owen Clancy and Murray Pittock (Edinburgh, 2007), pp. 273-85 (pp. 276-7). 
foundation narratives: the English had Geoffrey of Monmouth's Brutus foundation story, for instance, while the French had Pharamond, both narratives which were being replayed in scholarly circles at the turn of the sixteenth century. ${ }^{10}$ The political importance of foundation myths was not lost on Douglas, even though the Scots were able to deploy Gathelos and Scota as Scottish founders in opposition to the Brutus myth. ${ }^{11}$ Crucially, in the Aeneid, divine ordination and prophecy justifies Aeneas' leadership and his actions for a greater cause. That too might have had easy currency in some political discourse in sixteenth-century Scotland: while James VI's arguments for divine right were several decades away, James IV's accession required at the very least the management of parricide, so a text that allowed a hero to grow into his divine destiny might be deemed particularly appropriate. ${ }^{12}$

On the other hand, examples of pessimistic readings of Virgil were also found in the early modern period. Such readers, including Ariosto and Shakespeare, are alive to the ambiguities of Aeneas' behaviour, and the problems with the Trojan invasion. In the case of the Eneados, it is obvious from the Prologues IV and VI that Douglas was troubled by the treatment of Dido and Aeneas' visit to the Underworld in those books. Those issues arise from the collision between Virgil's narrative and the tenets of Christian faith, and Douglas's understanding of previous vernacular representations of the text. Both of these in turn connect

${ }^{10}$ See R.E. Asher, National Myths in Renaissance France: Francus, Samothes and the Druids (Edinburgh, 1993) and T.D. Kendrick, British Antiquity (London, 1950).

${ }^{11}$ Steve Boardman, 'Late Medieval Scotland and the Matter of Britain', in Scottish History: The Power of the Past, edited by Edward J. Cowan and Richard J. Finlay (Edinburgh, 2002), pp. 47-72. For Douglas's engagement with the matter, see Polydore Vergil, Historia Anglica (Basle, 1534), p. 50, and Denys Hay, Polydore Vergil: Renaissance Historian and Man of Letters (Oxford, 1952), pp. 18,110 .

${ }^{12}$ See Macdougall, James IV, pp. 24-44 and also Anna McHugh's essay in this volume. 
to the nature of Douglas's imagined audience: firstly an individual with particular resources (Sinclair), but then broadening to include schoolmasters and others able to read the vernacular. In contrast, the conclusion to the twelfth book of the Aeneid, Virgil's last, challenges both Latin and vernacular readers. That ending was so disconcerting that a number of poets, not just Maffeo Vegio, took it upon themselves to 'finish' the Aeneid, to establish Aeneas as the victorious King with Lavinia as his prize bride and to mitigate the shock of Turnus' death. ${ }^{13}$ Douglas translates Vegio's book, a text he would have found in Badius Ascensius' edition: given his apparent unease in undertaking this part of the translation, considering the potential political significance of his work repays further examination. ${ }^{14}$

Several critical accounts have considered this. Most sympathetically, Douglas Gray challenges David Coldwell's assertions that Douglas manipulates the poem to display particular political readings: in short, 'the idea of Aeneas as the model for a prince has been exaggerated'. ${ }^{15}$ Having said that, Gray then goes on to demonstrate how Douglas portrays Aeneas as a 'gentill wycht' and how he does justice to the complex Virgilian figure, rather than reduce him to a convenient one-dimensional type. However, demonstrating Douglas's faithfulness towards Virgil's ambivalence does not in itself acquit the Eneados of presenting Aeneas as the model for a prince, it simply acknowledges that Douglas, tied as he is to the Aeneid as if to a stake (I.Prol.297-302), is reflecting the challenges as well as the triumphs of Aeneas' journey. Gray's reading downplays the significance of the political situation of the

\footnotetext{
${ }^{13}$ Wilson-Okamura, Virgil in the Renaissance, pp. 237-47, esp. p. 239, n. 174.

${ }^{14}$ Douglas used Badius's 1501 edition of the Aeneid. See Bawcutt, Gavin Douglas, pp. 99-102. For Douglas's unease, see XIII.Prol.1-198.

${ }^{15}$ Douglas Gray, 'Gavin Douglas and "the gret prynce Eneas", Essays in Criticism 51 (2001): pp. 18-34, esp. p. 20.
} 
early 1500s when the Eneados was composed; he also does not engage with the oddity of having a text about a prince written by a man who, even before 1513, might expect to wield significant political influence, simply by reason of who he is. The natural focus on Aeneas, moreover, overlooks the role of Turnus: presented in opposition to Aeneas, he is nevertheless a man who seeks to preserve the independence of his people in the face of determined invasion.

In his opening prologue to the Eneados, Douglas identifies Henry, third Lord Sinclair, as the inspiration for the translation, saying that Sinclair had advised him to translate either Homer or Virgil. Sinclair is known as a patron of literary culture: he owned and curated the manuscript in which the Kingis Quair is preserved, as well as other significant texts. ${ }^{16}$ Despite his literary interests, however, there is no evidence that he undertook advanced university studies; it might even be a reasonable speculation that he would have only had the most passing acquaintance with either Homer or Virgil, and those mostly through vernacular references. He first appears in the records when he was recognized as 'Chief of that blude' on 26 January 1488-89; he was married before 4 December $1488 .{ }^{17}$ While it is hard to calculate his age precisely, given that he was still young enough to accompany the king on the invasion of England in late summer 1513 (in company with Douglas's elder brothers but in contrast to Douglas's father, the Earl of Angus), and that he would have most probably been in his late teens or early twenties when he married, it is likely that he was born around 1465-70, making him roughly Douglas's contemporary. Although Bawcutt suggests that Douglas might have hoped for some material reward from his patron, she also points out that Douglas addresses

\footnotetext{
${ }^{16}$ See Julia Boffey and A.S.G. Edwards, 'Bodleian MS Arch Selden. B. 24: The Genesis and Evolution of a Scottish Poetical Anthology', in Older Scots Literature, pp. 14-29.

${ }^{17}$ See Scots Peerage, vol. 7, pp. 571-2.
} 
him as his peer, or his 'cousyng' (Direction 3) ${ }^{18}$ If this is the case, then it is probable that they knew each other at James IV's court, in the 1490s and early 1500s, around the time of The Palice of Honoure. Sinclair was more successful than Douglas at keeping royal patronage: the Angus kin were not consistently in favour and Douglas had to wait for his bishopric until after James IV's death, while Sinclair rose in royal service, being appointed as Master of Artillery in 1511 and captain of the Great Michael in 1512. If the protagonist of The Palice looks more like Douglas himself, then Sinclair, as a military man, looks closer to models of nobility depicted in the Aeneid.

Of course the parallels are not sustained: there is no suggestion that Sinclair will found an empire or visit the underworld. Nevertheless, Douglas's choice of dedicatee looks particularly pertinent in the light of one of the most provocative recent readings of the Eneados, by James Simpson. ${ }^{19}$ Simpson sees the Eneados as a text that 'makes no genealogical claim whatsoever, and offers access to a model of nobility, both poetic and monarchical' ${ }^{20}$ As a bald statement, this fits more neatly with The Palice of Honoure, Douglas's first work, dedicated to James IV: that poem correlates poetic endeavour with martial success as a means of gaining honour. If the king is not the only recipient of honour, then the corollary is that the monarch may not be the only beneficiary of advice material. As Mapstone has argued, a good deal of Scottish material is directed towards audiences of

\footnotetext{
${ }^{18}$ Bawcutt, Gavin Douglas, pp. 92-3.

${ }^{19}$ James Simpson, Reform and Cultural Revolution 1350-1547, Oxford English Literary History 2 (Oxford, 2002), pp. 68-103.

${ }^{20}$ Simpson, Reform and Cultural Revolution, p. 74.
} 
magnates and lairds, so Simpson's view of the Eneados can find its place easily in Scottish tradition. ${ }^{21}$ However, Simpson elaborates his view:

Literate bureaucrats and poets had claimed nobility of soul against aristocratic privileges throughout the medieval period, but the political conditions of the early sixteenth century ... give a dramatic impetus to the idea. In this social environment, literacy and the capacity to imitate classical models become the hallmarks of a newly defined nobility, according to which nobility is produced by analogy rather than genealogy. ${ }^{22}$

Simpson goes on to describe Douglas's family background as a 'complication', but such a view underplays the significance of his family ties. The Douglases, Black and Red, had been a major, often disruptive, presence in Scottish politics since the fourteenth century; even as a younger son, Douglas cannot escape his kin. The Palice of Honoure might suggest that, in addition to his birth, Douglas had a claim on the 'nobility of the soul', if that term can be said to include writing as a legitimate path to honour. As the example of Cicero in the Palice of Honoure shows, rhetoric itself can be a winner for the realm, although more commonly it acts as judge for the honour of others ( $P H$ 1770-4).

At the very end of the paragraph quoted above, Simpson alludes to Douglas's readers. However, Douglas does not address his poem to 'literate bureaucrats and poets', but to Sinclair in the first instance, and then more generally to schoolmasters ('translatar direkkis', 41-8) and 'euery gentill Scot' at the end ('Exclamatioun', 43). In the light of the opening dedication, Simpson's argument about 'nobility ... produced by analogy rather than

\footnotetext{
${ }^{21}$ Mapstone, 'Was there a Court Literature?', pp. 414-15 and 'Older Scots Literature and the Court', pp. 275-9.

${ }^{22}$ Simpson, Reform and Cultural Revolution, p. 75.
} 
genealogy’ sits oddly. Neither Douglas nor Sinclair earned his position entirely through his skills, but were enabled by their inherited nobility and rank. The same might be said of Aeneas: while on the one hand, his journey from Troy to Italy refines him from one prince among many to the leader, firstly of his family, then his own followers, and then to the generalship of a larger army of various peoples, on the other, such a fate was divinely written and enforced, an argument used by many kings and nobles when regarding their own births. For such an audience, the Aeneid would seem to be useful to remind Sinclair and Douglas how to reflect their noble births in their behaviour, rather than to transcend their origins with their literary responses. From a noble pen, such a reading of the Aeneid is harder to differentiate from medieval romance and indeed from the prevalent advice-to-princes motifs of Older Scots: the Sinclairs, after all, had a manuscript of Gilbert Hay's prose works in the family library. ${ }^{23}$

At the same time, the composition of the Eneados sits between the 1496 act requiring all barons and freeholders to send their sons to school and the lament over the ignorance of the nobility in the Historia Maioris Britanniae (1521) by Douglas's friend, John Mair. There Mair complains that 'the [Scottish] gentry educate their children neither in letters nor in morals - no small calamity to the state'. Proper tutors 'learned in history, upright in character' would be able to inculcate from 'the example of the Romans, whose most illustrious generals were men well skilled in polite learning; and the same thing we read of the Greeks, the Carthaginians, and the Persians'. ${ }^{24}$ Mair specifically identifies history and

\footnotetext{
${ }^{23}$ Sally Mapstone, 'Older Scots and the Fifteenth Century', in Older Scots Literature, pp. 1-13 (pp. $5-6)$.

${ }^{24}$ John Major, A History of Greater Britain, as well England as Scotland, translated by A. Constable, Scottish History Society (Edinburgh, 1892), p. 48.
} 
Roman practice: the Aeneid as a source text - a pseudo-historical account written for the first Roman emperor - might fit that brief. Without claiming that Douglas was participating in some national programme of noble education, nevertheless he directs his translation to a fellow nobleman, one enjoying a distinguished military career. By the end of the work, Douglas is more expansive — or perhaps less idealistic — about the likely audience for the Eneados. He refers to it as a crib for school masters, not necessarily Simpson's 'bureaucrats and poets', although possibly responsible for educating some of them. Such a socially polarized audience indicates the dangers of limiting the Eneados to a single message, as well as making such a message hard to identify; in that, Gray is right. However, given that the Latin protagonist was widely read as an exemplar, to ignore the potential 'relatability' of the Eneados to Scottish noble experience is also to elide some of its richness.

The first question has to be about the nature of nobility. Douglas helpfully offers some discussion of this in two of the prologues. Cited by Simpson as the most important, the ninth prologue addresses nobility directly. ${ }^{25}$ There is a strong emphasis on moral behaviour, 'Honeste is the way to worthyness/ Vertu, doutless, the perfyte gait to blyss'(IX.Prol.7-8); only one line seems pointed, 'Oyss not thy mycht abufe thyne awin degre' (IX.Prol.15). Such a warning might apply to those climbing up to the Douglases, but also perhaps to his aristocratic peers. After the first eighteen lines, Douglas returns to rhymed couplets, for a longer discussion regarding register and translation: 'thar suld na knycht reid bot a knychtly taill' (IX.Prol.44). This means that broom should be replaced by laurels, spaniels rather than mastiffs, goshawks rather than gleds. It is a very particular view of the knightly life, one which is directed towards his patron:

And for I haue my wark addressyt and dycht

\footnotetext{
${ }^{25}$ Simpson, Reform and Cultural Revolution, p. 72
} 
I dar sa, baith to gentil barroun and knycht,

Quahis name abufe I haue done notyfy

And now of prowess and hie chevelry

Behuffis me to write and carp a quhile. (IX.Prol.87-91)

This reassertion of his patron's identity underlines Douglas's presentation of barony and knighthood as significant to Sinclair, and presumably himself, rather than — at this point — to an audience interested in art for its own sake. The initial verse form, and accompanying style of diction, therefore, are only one element of the entire work. The change in verse form, from intricate internal rhyme to relatively plain couplets, suggests perhaps that straightforward narrative is a more effective means of communicating nobility, even if that is never precisely defined; moreover a rollicking story is better placed to capture the intended audience. While the Eneados never reaches the 'lowness' of fabliau diction, its source means that it ranges widely, from philosophy to seamanship. Yet Douglas's statement equally implies that the range of the whole poem is entirely suitable for the nobility, because of its subject and because of its narrative: Book IX is merely a book where 'hie chevelry' and combat dominate.

Prologue XI returns to the question of nobility. Its opening looks promising: it talks about 'prowes, but vyce, is provit lefull thyng' (XI.Prol.9), but this too is qualified by the exemplars, Machebeus, Ioshua, David, and the archangel Michael. This list bears comparison with the Scottish examples used in The Palice of Honoure, namely Gregor, Kenneth, and Robert I (PH 2026-9), as all but Michael are leaders who are associated with rightful resistance to invasion. Yet as both Simpson and Gray point out, in this prologue, the presentation segues into a discussion of the Christian as knight, battling against the world, the flesh, and the devil: indeed, Douglas says 'To speke of moral vertuus hardyment/ Or rathar of 
dyvyne, is myne entent' (XI.Prol.25-6). ${ }^{26}$ Douglas is drawing on ultimately Pauline models here, ${ }^{27}$ but there are two stanzas where earthly power breaks through.

Strang fortitud, quhilk hardyment cleip we,

Abuf the quhilk the vertu soverane

Accordyng pryncis, hecht magnanymyte

Is a bonte set betwix vicis twane:

Of quham fuyl hardynes clepit is the tane

That undertakis all perrellis but avice;

The tother is namyt schamefull cowardyce,

Voyd of curage, and dolf as any stane. (XI.Prol.33-40)

Most of this is conventional, but the pitch, of the virtues of princes, seems more particular. Douglas presents an Aristotelian fine line between 'fuyl hardynes' (foolish boldness) and 'schamefull cowardyce'. His models step up to fight as required, but do not undertake battle without preparation. There is nothing radical about such a temperate view, although it might seem more pertinent when addressed to a military officer of a king known to be interested in chivalric endeavour. It also reflects on the figures of the narrative it frames: the standard presentation of Aeneas is as a man who grows into self-control and temperate government. Yet, by the end, when Aeneas is held up as the model of one who suffers for his faith, the analogic rather than the literal model of nobility predominates, since his achievements (and those of other pagans) are necessarily still overwhelmed by Christ's sacrifice.

\footnotetext{
${ }^{26}$ See Simpson, Reform and Cultural Reformation, p. 72 and Douglas Gray, 'Gavin Douglas', in Companion to Medieval Scottish Poetry, pp. 149-64, esp. p. 163.

${ }^{27}$ See Ephesians 6.16.
} 
Although the prologues open questions about the nature and exercise of nobility, they are not explicitly an instruction manual for the elite. Douglas is apparently at least as much concerned with his representation of Virgil's text and hero. As indicated earlier, however, in representing Aeneas accurately, Douglas is necessarily engaged with a critical tradition that considers Aeneas as a model, whether of excellence or critique. Kallendorf describes the positive view of Aeneas as a pattern that repeats over centuries: moreover, he suggests that this model of Aeneas is particularly suited to imperial nations, for its narrative is a triumph of colonization and ultimate conquest. ${ }^{28}$ Although James III had declared Scotland an empire in the 1480s, the Scots' national narrative was not consistently imperialist. ${ }^{29}$ The incorporation of the Northern Isles (with which the Sinclairs were closely involved) and the suppression of the Lordship of the Isles were internal acts of conquest; ${ }^{30}$ but national narratives, most obviously the Bruce and the Wallace, tended to represent the Scots as being subject to unwarranted invasion rather than seeking conquest themselves. So a straightforwardly imperialist translation of the Aeneid would be at odds with much of Douglas's vernacular tradition. At the same time, Douglas's expressed duty of care towards Virgil's text and the regular use of Aeneas as an exemplar militate against assuming an entirely pessimistic reading of the Trojan's adventures. Rather, I propose that Douglas mediates between these poles, displaying his loyalty to Virgil, but also offering a nuanced view of a particular kind of

${ }^{28}$ Kallendorf, The Other Virgil, pp. 6-16 for the first articulation of this argument.

${ }^{29}$ See Roger A. Mason, 'Humanism and Political Culture', in Kingship and the Commonweal: Political Thought in Renaissance and Reformation Scotland, edited by Roger A. Mason (East Linton, 1998), pp. 104-38; William Ferguson, The Identity of the Scottish Nation: An Historic Quest (Edinburgh, 1998); and Boardman, 'Late Medieval Scotland'.

${ }^{30}$ Norman Macdougall, James III: A Political Study (Edinburgh, 1982), pp. 90-1 and Jane Dawson, Scotland Reformed 1488-1587 (Edinburgh, 2007), pp. 43-7, 71-4. 
military nobility. To consider this proposition, I examine three sections in the later books, specifically Anchises' presentation to Aeneas in the Underworld in Book VI; the final speeches and combat in Book XII; and the opening chapters of Book XIII.

The imperialist strain of the Aeneid is perhaps most obvious in prophetic passages, especially in Books VI and VIII. These episodes outline allusively the future of Rome, the city that Aeneas' descendants will found some time after the poem. Both accounts skip from figure to figure, relying on the reader's knowledge of Roman history, and while Douglas occasionally extends the metaphors and descriptions, he does not provide in-text glosses to explain the figures' significance. In Book VI, the encounter with Anchises takes up the last four chapters of the book. It is the point where Anchises confirms his son's destiny and that of his descendants. By chapter 14, the narrative moves beyond the founding of the Roman city and towards the Roman imperium. Lucius Iunius Brutus is identified as the first consul; others named include Camillus and the Scipiones. In the middle of the chapter, a division imposed by Douglas rather than Virgil, is Anchises' lament regarding the civil war between Caesar and Pompey:

' $\mathrm{O}$ my childring, cum nocht in uss to hant

Sik fremmyt batalis, bot your curage dant;

Exers yhe neuer yowr vailyeand forss,' quod he,

'Amangis the entralis of your awin cuntre.

And $\mathrm{O}$ thou Cesar, thou formast in the press

Cum of hevinly kyn, abstene and cess;

Myne awin lynage, obeys my command,

Do cast sik wapynnys fer furth of thy hand.' (VI.14.63-70) 
Douglas maintains the metaphor of the body ('entrails') for Virgil's viscera, additionally stressed by the reassertion of Anchises' voice ('quod he'). ${ }^{31}$ Douglas's patterning juxtaposes 'hevinly kin' with 'myn awin lynage' to stress the responsibility Caesar bears to behave well. The irony of Anchises' wish is key to the irony of the prophecy, since for all the good he can predict, there is necessarily ill too. Nevertheless, Douglas, following Virgil, chooses to put the responsibility for peace on Julii, rather than on those challenging their authority.

If Caesar and Pompey are at the heart of this chapter, Quintus Fabius Cunctator concludes it. Fabius Cunctator is famous for winning by not fighting, but by constantly delaying (hence his cognomen). Douglas describes him thus:

Thow are that ilk mast souerane Fabius bald

Quhilk only, throu thy slycht and tareyng

Restoris the common weill of our ofspryng. (VI.14.100-2)

Virgil's description is briefer: unus qui nobis cunctando restituis rem (Aen. 6: 846). Two features stand out. The first is the use of 'common weill' for 'res'. This becomes Bellenden's standard translation of res publica, although the first DOST citation is in fact Dunbar. ${ }^{32}$ Douglas's modification of 'common weill' with 'of our ofspryng' however needs some attention. Virgil's nobis allows an expansive interpretation, where 'us' means 'us Romans' rather than 'us Anchisidae'. In contrast, Douglas's translation is more exclusive, unless Anchises' paternalism here (unlike his specific rebuke to Caesar (68-9)) incorporates all Romans. The broader incorporation would make more sense at the end of a long list of Roman statesmen, not all of whom were descendants of Aeneas; at the same time it insists on

\footnotetext{
${ }^{31}$ Quotations from the Aeneid are taken from Virgil with an English translation by H. Ruston Fairclough, revised by G. P. Goold, 2 vols (Cambridge MA, 2014). This reference is Aen. 6.833 .

${ }^{32}$ DOST: 'Commoun wele n.'.
} 
a single vision of Roman identity. In a Scottish context, such alignment would equate the royal line with the realm. That alignment is reinforced by 'common weill'. In addition, the term also possibly puns on 'well', a source of water, suggesting something nourishing from which all Romans ('our ofspryng') will come to draw, whether that be identity or well-being. This small section then stresses a common cause between the son of Aeneas and the Roman nobility - appropriate enough for a text directed to a magnate and royal servant.

The second point to query is Douglas's introduction of 'slycht', cunning rather than brute force. Arguably, it reflects the initial Roman response to Fabius, as described by Livy; but it nevertheless stands in contrast to the physical aggression of Pompey and Caesar, rather as 'entralis' sit oddly with 'common weill'. The conclusion of the chapter celebrates the intellectual approach to warfare rather than the physical. Such a contrast stands out still further because of the equivocal attitude to Caesar and Pompey as warriors: Fabius' approach of minimizing damage and casualties by drawing the alien enemy away is the counterpoint to the civil war mentioned earlier, and it gains further attention from Douglas's location of it at the end of the chapter. The inference of a political message seems to be supported by Douglas's chapter heading immediately following:

Anchises gevis Eneas gud teching

To gyde the pepill vnder his governing. (VI.15 heading)

At the very least, the heading forces the reader to consider what teaching Eneas might already have had.

Chapter 12, the last and the longest chapter in Book VIII-135 lines_-is headed 'Eneas mervellys of the storeys seir/ Wrocht be Wlcanus in hys armour cleir' (VIII.12). Although there are several scenes in this section, there really is only one story: the battle of Actium and its aftermath. Douglas's heading, therefore, is not particularly informative, stressing more Eneas' reaction. The narrative contrasts to Anchises' reflection on Caesar and Pompey, 
discussed above, for while the conflict between Caesar and Pompey was unequivocally a civil war, the battle here is between Cesar August Octuyan and the Italyanys and Romans, and Marcus Antonyus and 'ane huge rowt and multitude' (VIII.12.30) of 'barbaryanys' (VIII.12.24). In the triumphal narrative, set in Rome, Octavian's victory procession allows him to be justified in his warfare: the suppression of rebellion from the east is to be celebrated. In 1497, the Lordship of the Isles was incorporated into the direct authority of the Scottish crown: to map that event, some sixteen years earlier, on to this scene is precisely the kind of political reading that recent critical practice would rightly resist. ${ }^{33}$ Yet Douglas's translation elaborates unexpectedly. Where Virgil has:

Maxima ter centum totam delubra per urbem

Laetitia ludisque viae plausuque fremebant. (8:716-17)

Douglas's translation is this:

Our all the cite, in maist singular ioy,

The blysfull fest thai makyng man and boy

So that thre hundredth ryall tempillys dyng

Of ryot, ryppet and of revellyng

Ryngis, and of the myrthful sportis seir

The stretis soundyng on solacious maner. (VIII.12.101-106)

The heavy alliteration is all Douglas's: the two runs suggest celebration at the conclusion of the war. At the same time, however, Douglas's language suggests much less restraint, and indeed the probability of disorder. This is particularly true of the first run, where 'ryot' has

\footnotetext{
${ }^{33}$ See Dawson, Scotland Re-formed, pp. 43-7; Roderick J. Lyall, 'Politics and Poetry in Fifteenthand Sixteenth-Century Scotland', SLJ 3.2 (1976): pp. 5-29.
} 
generally negative connotations in DOST. ${ }^{34}$ Such anxiety around the effects of warfare sits well with Simpson's bureaucratic nobility: given Douglas's identity as a burgh churchman as well as a scion of the chivalric nobility, expressing such concerns in a work directed to another nobleman might have general moral point. ${ }^{35}$

Throughout the Aeneid, from the sack of Troy, to Carthage, to the Trojan invasion of Italy, there are anxieties about war, most memorably expressed as moments of pity for those who lose out because of divine decisions beyond their control. In medieval terms, it is the sympathy for the innocent victims of fortune. From a Scottish perspective, the divine rights of the Trojan invaders might be a particularly bitter pill. This extract, for instance, brings together words that seem familiar from other poems:

Quhen we, as thrallys, leif sal our natyve land

And onto prowd tyrrantis, hess the ovirhand

Salbe compellit as lordis till obey,

That now, thus sleuthfully, sa fant and fey

Hufys still on thir feldis as we war ded

And for our self list schape for na remed. (XII.5.37-42)

As it happens, the collocation of thralls and tyrants does not appear in the Wallace, and tyrants do not appear in the Bruce at all, but the rhetoric of thralldom is nevertheless allusive. For Hary, Wallace's achievement is that 'Scotland he [Wallace] fred and brocht it off thrillage' (Wallace XII.1235); for Barbour, Bruce's Bannockburn speech has this couplet:

\footnotetext{
${ }^{34}$ DOST: 'Riot n.'.

${ }^{35}$ For bureaucratic concerns regarding war generally, see James D. Tracy, The Politics of Erasmus: A Pacifist Intellectual and his Political Milieu (Toronto, Buffalo, 1978).
} 
'Ye mycht have lywyt in-to threldome/Bot for ye yarnyt till have fredome' (Bruce XII.281-

2). ${ }^{36}$ For a readership familiar with this material and with the self-presentation that goes with it, it is hard not to read the speech from the Eneados sympathetically.

Yet the passage from the Eneados occurs in a speech by the nymph Juturna, intended to rouse the Rutulians against the invading Trojans. Juturna is Turnus' sister, acting in disguise under command from Juno, to prevent Turnus from meeting Aeneas in single combat. She is, as Douglas says later, a virago, a woman doing a man's office, so the patriotic rhetoric belongs to a woman, doubly deceitful in disguise, under instruction from a female deity to interfere with Jovian ordinance. Gender in and of itself is not necessarily a marker of unreliability in the Aeneid or the Eneados, but the manner in which Juturna undertakes her role, particularly in her use of the Rutulians to save her brother, sacrificing the many for the individual, as well as Turnus' function as anti-hero surely makes her questionable. For Douglas then to give her language evocative of poems such as the Bruce and the Wallace brings under scrutiny those discourses of thralldom and tyranny, while maintaining the Aeneid's narrative.

Slightly before Juturna's directed interference, Turnus strikes this pose when confronting King Latinus:

' $\mathrm{O}$ thou maist souerane fader, I the pray,

To salue my honour, thou wald do away

Thir cures, thochtis and solicitude

For me thou takis; and, schortly to conclude,

${ }^{36}$ See Hary's Wallace, edited by M. P. McDiarmid, 2 vols, STS (Edinburgh and London, 1968-9), vol. 2, p. 115 and Barbour's Bruce, edited by M. P. McDiarmid and J.A.C. Stevenson, 3 vols. STS (Edinburgh and London, 1980-85), vol. 3, p. 38. 
Suffir me forto plege my death in wage,

For gloryus renovn of vassillage.' (XII.1.117-22)

In contrast to Juturna's speech, this extract does not foreground the patriotic element. Instead, it focuses on the chivalric: 'honour', 'gloryus renovn of vassilage'. Most of the chapter has been given to Latinus, who attempts to dissuade Turnus from war, arguing that 'Now of our recent blude, as noterly kend is/ The flude of Tibir walxis hait agane' (XII.1.88-9). For Latinus, his duty as King is to preserve his people from war, and from the "chance of batale variabill' (XII.1.105). Turnus speaks at the end of the chapter, and his speech gives the impression that he is interested in his reputation rather than his people; for a moment, the cause - repelling the invader - is lost. Here, not least because of the way in which Douglas arranges the chapter to give far greater length to Latinus, and to make Turnus' response seem rather abrupt, is the other side of the chivalric ideal. Despite Turnus' cause being more in tune with Scottish self-presentation, his focus on his own reputation and his accusations of cowardice against Eneas rather diminish his chivalric glamour. While the poem does not necessarily critique directly James IV's hostilities with England in 1512-13, the language nevertheless suggests some anxieties about the presentation and purposes of war.

In contrast to Turnus, Aeneas is the politician (or coward, as Turnus might say):

Gif that sa fair fortoun betydis me

Ne will I not command Italianys

Tobe subiect, nor obey the Troianys,

Ne yit this realm desyre I not to me;

Bot athir of our pepill mot go fre,

Onthrall, onvenquyst, in lawys all evynly

Confiderat in perpetuall ally. (XII.4.72-8) 
Such a pragmatic settlement contradicts the tales of chivalric glory envisaged by Turnus. Eneas also deploys the language of liberation ('fre', 'onthrall', 'onvenquyst') and emphasizes the alliance. At this point in Book XII, Turnus' rashness and aggression determine his annihilation, whether or not the reader sympathizes with his position as a defender of his homeland from invasion. For at the end of the twelfth book of the Aeneid Aeneas fails to maintain his pragmatism when Turnus begs for mercy, instead avenging the death of Pallas when he lays eyes on the baldrick Turnus looted from the body. ${ }^{37}$

Douglas divides Book XII into fourteen chapters: the last two divisions seem particularly significant in determining the reader's response. Chapter 13 has the heading: 'Quhou Iupiter and Iuno dyd contend/Eneas stryfe and Turnus fortill end' (XII.13). What that outcome of the duel will be is underlined by the word ordering in the second, where Eneas is the primary figure, closely associated with the fight, and Turnus - an equally important grammatical item—seems merely doomed to die. That the outcome is almost entirely dependent on the divine will of Jupiter is evident from the heading and from the chapter itself. Juno turns out to be willing to sacrifice Turnus, provided that Jupiter 'ne wald the ald inhabitantis/ Byd change thar Latyn name nor natyve landis/ ne charge thame nother tobe callit Troianys' (XII.13.779). When Jupiter grants her request, her attitude to Turnus is cavalier:

Iuno annerdit, and gaue consent heirto,<smiles>[AlH2]</smiles>

And in the meyn tyme onto the hevyn hir drew, And left the cloud, and bad Turnus adew. (XII.13.118, 121-2)

'Bad Turnus adew' is Douglas's addition: Douglas emphasizes that his rights, his service, even his prayers, do not demand Juno's loyalty to his cause, provided she gets her wish. The

\footnotetext{
${ }^{37}$ For further discussion, see Gray, 'Gavin Douglas and Eneas', pp. 30-2.
} 
rest of the chapter demonstrates the first effects of Juno's abandonment, as Turnus is assaulted by the Dirae, a sign by which Juturna realizes her defence of her brother is pointless. Overall, the chapter stresses Turnus' vulnerability to figures and decisions beyond his control, for it does not matter if his quest, as a fight for maintained sovereignty, is right, it will be sacrificed to a more powerful will. Other figures in Scottish narratives face similar crises, including the fictional Golagros and the slightly less fictional Wallace of Hary. Again, without reducing the Eneados to a direct political commentary, there are unexpected parallels to draw.

Juno's withdrawal has already confirmed the outcome of the last chapter in Book XII. Its heading is curious: 'At Eneas Turnus a stane dyd cast/ Bot Eneas hass slane hym at the last.' (XII.14).While it refocuses attention on Eneas and Turnus as the only figures in the chapter, it also characterizes them differently, Eneas as victor, Turnus as stone-thrower. For an audience versed in Biblical narrative, such an image is wrong: David the stone-thrower is the victor over Goliath. Of course, Turnus is no shepherd boy: the stone he hurls ineffectually is one that usually takes twelve men to lift (XII.14.33). He is also well aware of his impending doom for as he says to Eneas, 'Thy sawis makis me not agast, perfay; It is the goddis that doith me affray/ And Iupiter becummyn my ennemy' (XII.14.23-5). Nevertheless, a hint of irony remains, for David won because God was on his side, whereas Turnus will lose because the gods have abandoned him.

For most of the chapter (20-123), Turnus is the foregrounded figure: we hear his acknowledgement of the gods, see the episode with the stone, experience his disorientation, and finally hear his appeal for mercy. He requests only that:

My body, spulyeit and the life byreft,

Onto my folkis thou may rendir eft. 
Extend na forthir thy wraith and matalent. (XII.14.117-18, 23)

In classical readings, the plea to return the body evokes Hector and Antigone; in contemporary Scottish readings, Turnus' humility in defeat and his request for an end to hostilities after his death might be more reminiscent of Golagros, and his defeat by Gawain. Eneas' response draws attention back to him (124-51), so it is shocking when Eneas has his mind changed by a desire for revenge. At the end, Eneas ceases to act like a statesman and a politician, and returns to violence.

And sayand thus, full ferss, with all hys mayn,

Law in hys breist or cost, lay hym forgayn,

Hys swerd hess hyd full hait; and tharwithall

The cald of deth dissoluyt hys membris all.

The spreit of lyfe fled murnand with a grone,

And with disdeyn vnder dyrk erth is goyn. (XII.14.149-54)

The last line of the Aeneid, vitaque cum gemitu fugit indignata sub umbras (Aen 12:952), has already occurred in Virgil's poem at 11.831 to describe the death of Camilla. ${ }^{38}$ Douglas's translation in Book XI is very similar as well: 'The spreit of lyfe fled murnand with a grone/ And with disdene dovn to the gostis is goyn' (XI.15.145-6). Thus, Douglas follows Virgil in linking the deaths of Camilla and Turnus, and so his presentation of Turnus' death benefits from the transferred pathos: Camilla's role as noble fighter is much less ambivalent than Turnus', not least because she does not meet Aeneas in single combat, and her death scene is more elaborated. In Book 12, despite Aeneas being the main actor, at the point of death the reader's attention is returned to Turnus and the effects of violence. One of the most striking

\footnotetext{
${ }^{38}$ I would like to thank Professor Bawcutt for pointing this out.
} 
features is the Latin indignata, translated by Douglas as 'with disdeyn'. In the Aeneid, this must mean 'raging at the unfairness of fate'; 39 'disdeyn' usually carries connotations of contempt and indignation, but here anger would seem a better reading. ${ }^{40}$ 'Disdeyn' occurs at one other point in the Eneados: in Prologue IV, Douglas describes Dido as killing herself 'for disdeyn' (IV.Prol.256). In this context, Douglas is not bound by Virgil's text, and his choice of this word, again surely having connotations of anger and railing against fate, must link Dido to Camilla and Turnus, as people sacrificed for the gods' grand plan. Such an experience cannot have been entirely alien to anyone dependent on royal favour.

The ending to the Aeneid is shocking and abrupt: hence Vegio's composition of the thirteenth book. Because of the recurrent moments of prophecy in the Aeneid, particularly in Books VI and VIII, but elsewhere too, a thirteenth book is not necessary to conclude the story: Rome will be founded. Vegio's book — and Douglas's translation — then is concerned with immediate history, to the aftermath of the conflict that ends Book XII. ${ }^{41}$ Although the first chapter heading ('Rutulian pepill, eftir Turnus decess/ Obeys Eneas, and takis thame to hys pess' XIII.1) asserts Eneas' new power, the chapter itself is more equivocal. It opens thus:

As Turnus, in the lattir bargan lost

${ }^{39}$ See Virgil, Aeneid XII, edited by Richard Tarrant (Cambridge: Cambridge University Press, 2012), p. 341, n. 952.

${ }^{40}$ OED: ‘disdain, n.' .; DOST: 2a; ‘Disdene n.'.

${ }^{41}$ For Douglas's deployment of Vegio's book, see Kantik Ghosh, “"The Fift Quheill”: Gavin Douglas's Maffeo Vegio', SLJ 22 (1995): pp. 5-21 and Robert Cummings, “"To the cart the fift quheill”: Gavin Douglas' Humanist Supplement to the Eneados', Translation and Literature 4:2 (1995): pp. 133-56. 
Venquyst in field, yald further the fleand gost,

This marciall prynce, this ryall lord Enee,

As victor full of magnanymyte

Amyddis baith the rowtis baldly standis

That tobehald hym apon athir handis

Astonyst and agast war all hym saw. (XIII.1.1-7)

The focus is carefully weighted here. Turnus' fate is presented as matter of fact, what happens in war, but its statement in the first two lines and the use of 'as' to reinforce its contemporaneity with and necessity to Eneas' triumph. Eneas' presence is delayed, but he is surrounded by description, particularly as 'victor full of magnanymyte', so the reader's attention is delayed. However, the Latin people, at the end of the sentence dominate the next forty lines. In their response to Turnus' death, they lament their own, now vulnerable, situation:

That bargan and that weir fast wary thai,

And gan abhor of Mars the wild luf,

Quhilk laitly thay desyrit and dyd appruf.

The brydyll now refuss thai nocht to dre,

Nor yok thar nekkys in captiuite,

And to implor forgyfnes of all greif,

Quyet, and end of harmyss and myscheif. (XIII.1.20-6)

For all the glorification of Eneas in the first sentence, here there is no celebration of the right man winning, but a grim appreciation of the cost of war.

Eneas' 'magnamynyte' is demonstrated by his first speech, in which he laments Turnus' death as much as celebrating his victory. By the end, however, he is justifying his actions: 
'For, be the blyssit sternys brycht I sweir,

Neuer nane ostis nor yit armour glaidly

Agaynst you in batal movit I,

Bot constreynyt by your fury, as is kend

With all my forss I set me to defend

The Troian party and our awyn ofspryng

As, lo, forsuyth this was bot lesum thing.' (XIII.1.102-8)

Somehow, Eneas' imperial imperatives become the responsibility of the Rutulians: there is no reference to Eneas' displacing Turnus as a candidate for Lavinia's hand or challenging local power. Rather as Turnus realizes he is doomed towards the end of Book XII, so the Rutulians are brought to realize that they are subject to the Trojans, both in political act and in subsequent narratives. The futility of the war, at least from the side of the Italians, is reiterated by both Latinus and Daunus:

The huge slauchtir and myschews wrake,

And all the fludis walxyn red or brovn

Of mannys quelling gret and occisioun,

The lang abasit quakyng feirfull dreid

And hard laubour, quhilk in extreme neid

I in myne age sa oft hess ondertane,

In sa feill dangeris quhar remed was nane.

Bot now, Turnus, heir thou lyggis ded:

Quhar is the nobill renovn of thy youthed? (Latinus: XIII.3.114-22) 
Is this the notabill honour and lovyng

Of thy manhed, and glory of thy ryng?

Is this the gret wyrship of thyne empire?

O my deir son, quhilum thou bald syre,

Bryngis thou ws hame sikkyn triumpe as this? (Daunus: XIII.5.37-41)

The common thread here is Turnus' wilfulness and his dedication to war as a means of solving the Trojan threat, and attention is given to what his death has destroyed. These laments, in short, articulate the pity of war rather than its triumphs. In contrast to the Wallace, though, such pity is a motivation towards peace rather than revenge. Latinus moves quickly to discuss a marriage alliance with Eneas (XIII.6); Eneas responds in such a way that 'the Latynys .../ With vissage still beheld hym stupifak .../ Mayr evidently gan mervell he and he/Of hys gret warkis of reuth and sik piete' (XIII.6.205-10). Book XIII allows Eneas to reclaim his pietas and to proceed on his destiny; at the same time, it also emphasizes the destruction caused by war. Turnus is blamed in the same way that Dido is blamed, but the overall effect is to equivocate over the value of Eneas' destiny.

What, then, of the Eneados as advice to princes? The critical consensus against reading particular texts as direct and particular comments on specific political situations is based on sound argument: for the Eneados, such arguments rest on the probable length of its genesis (assuming Douglas alludes to his plans to translate in the Palice of Honoure), its status as a translation, and Douglas's commitment to reproducing the Virgilian poem. Moreover, the Scottish experience of war is hardly unique to the second decade of the sixteenth century. Nevertheless, there is something particularly poignant in the depiction of war's futility in last two books, which in turn reinforces some of the anxieties underpinning the visions in Books VI and VIII. As a piece of political argument, the Eneados is far too long and too ambivalent to be useful; as a provocation to reflecting on chivalric values and their impact on the rest of 
the commonweal, it might have had more success, particularly when circulating in the aftermath of Flodden in September 1513.

As The Palice of Honoure had suggested a move from erotic poetry to epic, so the Conclusion to the Eneados already suggests Douglas's withdrawal from poetry altogether ('My muse sal now be cleyn contemplative,/ and solitar, as doith the byrd in cage' (16-17)). Six weeks after the completion of the Eneados, Henry Sinclair and both of Douglas's elder brothers were killed at Flodden, alongside James IV; when the fifth Earl died in November of that year, Douglas's nephew, Archibald, became Earl, married the dowager Queen, and started a new chapter in Douglas relations with the crown. It may well be that Sinclair never saw the work dedicated to him, and even if he had, he would not have had time to reflect on the definitions of nobility explored within it. Nonetheless, the Eneados did attract an active noble reader, in the Earl of Surrey, for Surrey's translations of Aeneid 2 and 4 are in places dependent on it, although Surrey seems to have modelled his behaviour more on Turnus than on Aeneas. Such advice as Douglas offers in his translation and in his prologues is not clearcut moralizing; rather, it highlights the ambivalences and challenges of operating at high rank, and the responsibilities that brings. That in itself might have been interesting enough to Henry Sinclair and his contemporaries. 